11

\title{
Party Brands, Partisan Erosion, and Party Breakdown*
}

\author{
Noam Lupu \\ Chapter forthcoming in Party Systems in Latin America: Institutionalization, Decay, and \\ Collapse, ed. Scott Mainwaring, Cambridge University Press.
}

\footnotetext{
${ }^{*}$ For their comments and suggestions, I thank Allen Hicken, Geoffrey Layman, Scott Mainwaring and participants at the conference on "Party Systems in Latin America: Institutionalization, Decay, and Collapse" at the University of Notre Dame. This chapter draws in part on my work in Lupu (2016).
} 
The dramatic and sudden decline in the staying power of established political parties is one of the most puzzling features of Latin American democratic politics since the Third Wave of democratization. Between 1978 and 2007, one-quarter of the region’s established parties broke down, meaning that they suddenly became uncompetitive for national executive office. Parties that had only recently been major competitors were relegated to an average vote share of merely 6 percent. Their breakdowns severely deinstitutionalized these party systems, upending and fragmenting once stable systems (Mainwaring, Bizzarro Neto, and Petrova, this volume; Roberts 2014). ${ }^{1}$

How might we explain these deinstitutionalizing breakdowns? Scholars of comparative politics often attribute party breakdowns to poor performance by incumbent parties. Corruption scandals or poor economic stewardship, they argue, cause voters to reject the incumbent party en masse, leading the party to break down (e.g., Coppedge 2005, Dietz and Myers 2007, Kenney 2004). But bad performance is far more widespread than party breakdown, and established parties have survived some major economic crises. In the 1980s in Peru, for instance, President Alan García’s economic policies led to some of the worst hyperinflation in world history, peaking in 1989 at 12,378 percent. Still, at the end of García’s term, his Popular American Revolutionary Alliance (APRA) party received nearly a quarter of the vote and fell just 10 percentage points shy of the winner. Bad performance is undoubtedly important, but it is not the whole story.

Classical theories of party politics also offer little traction in explaining these cases. Cleavage-based theories expect parties and party systems to change when the politically salient

\footnotetext{
${ }^{1}$ In some cases, these breakdowns were associated with system-wide collapse (Morgan 2011; Seawright 2012), but such instances are rare. I focus on individual party breakdown because it is more frequent and because I think we can develop theories that travel across cases. A remaining open question is why individual party collapse is associated with different system-level outcomes across countries (see Roberts 2014).
} 
social cleavage shifts (e.g., Dalton et al. 1984, Sundquist 1983). Theories such as these are helpful in explaining long-term trends of party decline and evolution, but they are difficult to apply to rapid shifts in a party's electoral fortunes. The slow shifting of social cleavages is unlikely to explain the sudden breakdown of a party.

Other aspects of the electoral environment, however, may change more quickly. Established parties—organizations that have remained competitive over decades—have adapted to existing environments (Cox 1997). Major changes could therefore threaten their survival. Making institutional arrangements, such as the rules governing elections, more permissive could have dramatic effects on parties that had adapted specifically to the old arrangement (Benton 2001, Centellas 2009, Kenney 2004, Remmer 2008, Tuesta Soldevilla 1996). They could also ease the entry of competitor parties that threaten established ones (Van Cott 2005). Or decentralizing political or fiscal authority—reforms that swept the developing world in the 1990s_could undermine national parties by strengthening local politicians (Morgan 2011, Penfold 2009).

Parties might also confront new social environments, especially in the economically volatile developing world. The debt crisis that swept Latin America in the 1980s, for instance, dramatically altered the socioeconomic environment for politicians. Default and economic stagnation meant high unemployment and shrinking government budgets. For parties that relied on state resources to fund patronage machines, these changes could pose serious obstacles (Benton 2001, Cameron 1994, Golden 2004, Morgan 2011, Roberts 2003, 2014).

Those parties that can adapt effectively will survive these institutional or social changes, whereas those too rigid to evolve may disappear. If party organizations are too institutionalized, if they privilege entrenched groups, or if their activist base is too extreme, they may fail to 
accommodate changing voter preferences (Coppedge 2005, Seawright 2012). In the Latin American context, those that relied most heavily on patronage might have found it particularly hard to mobilize support without access to state resources (Levitsky and Way 1998, Morgan 2011). Alternatively, those that relied on clientelism might have been able to cushion themselves against the forces of electoral decline (Kitschelt and Wilkinson 2007, Levitsky 2003).

The crises and reforms of the 1980s and 1990s in Latin America undoubtedly challenged established parties. But politics is always dynamic; these same parties had adapted to dramatic social and institutional changes in the past. They had survived economic depressions, military dictatorships, even major revolutions. Indeed, established parties across the region—even some of those considered most institutionalized—did adapt to new and changing contexts. Some reneged on campaign promises and completely reversed their historic policy positions (Campello 2014, Stokes 2001), often forcing entrenched labor groups to swallow painful economic reforms (Burgess 1999, Murillo 2001). Others implemented more flexible internal procedures, severed links to certain interest groups, or adopted open primary elections, all in an effort to address changing public expectations.

Clientelism helped many Latin American parties maintain their local bases of support over decades. But parties that relied on patronage to drum up voter support also based their decades of electoral appeals on far more. Established parties, in fact, generated deep-seated loyalties that went far beyond any quid pro quo. In much of the region, supporters went to war for these parties or faced imprisonment and torture when they were banned by military regimes. In fact, clientelist parties often target many voters who already identify with the party (Nichter 2008, Stokes et al. 2013). And patterns of partisanship across Latin America suggest clientelism is not the basis for most voters' attachments to parties (Lupu 2015a). Moreover, clientelism 
alone, or the lack of it, is unlikely to account for the massive changes in the national electoral fortunes of established parties. The difference between parties that survived and those that broke down was millions of votes, and even the region’s most efficient political machines are unlikely to sway so many voters, particularly as clientelism also entails electoral costs (Weitz-Shapiro 2013). ${ }^{2}$

The institutional reforms and social transformations of the period were also not uniform enough across the region to explain the varied fortunes of established parties in different countries (see Eaton and Dickovic 2004, Tulchin and Selee 2004). Parties broke down in countries that did not decentralize at all, whereas others survived despite changes to the electoral rules.

Within countries, many of these changes should have affected all parties more or less equally. After all, it is countries that reform their electoral rules, and whole party systems that should be affected by decentralization. Yet it is individual parties that broke down. Arguments that focus on system-wide transformations have a hard time explaining why one established party collapses whereas others in the same country live to fight another day. One could argue that system-level changes affected some parties more than others, ${ }^{3}$ but these kinds of explanations would need to specify what made some parties more susceptible than others. An adequate explanation of party breakdown needs to grapple with the different outcomes both across and within countries.

\footnotetext{
${ }^{2}$ My evidence also contradicts claims that clientelism maintains partisan attachments. For instance, voter attachment to the PJ in Argentina declined in the 1990s even though the party ramped up its clientelistic efforts during this period (Levitsky 2003).

${ }^{3}$ For instance, one could argue that parties that historically relied more heavily on patronage were more likely to break down as a result of declining state resources. But many patronage-based parties in the region survived the neoliberal era, whereas those far less reliant on state resources broke down.
} 
Party breakdown is also fundamentally about the attitudes and choices of voters. It is individual voters who decide to reject an established party they themselves had just recently supported (see Morgan 2011, Seawright 2012). In fact, party breakdowns are preceded by declines in partisan attachments (Lupu 2016). Something more than anti-incumbency was at work. We need to know why individual attachments to the parties erode and why, and when, that erosion leads them to abandon their party at the polls.

This chapter builds on the general explanation of party breakdown offered by Lupu (2014, 2016) by expanding its scope and testing its congruity across a broad range of cases. During the 1980s and 1990s, politicians across Latin America implemented policies that were inconsistent with the traditional positions of their party, provoked internal party conflicts, and formed strange-bedfellow alliances with traditional rivals. I argue that these actions blurred voters' perceptions of parties' brands - the kinds of voters the parties represent - eroding voters' attachments to them. Without the assured support of a partisan base, parties became more susceptible to voters' short-term retrospective evaluations. Voters who now had no party attachments deserted incumbent parties when they performed poorly. What looked like erratic voters suddenly abandoning the established parties they used to support was actually the result of

a process of brand dilution. In this chapter, I examine whether the expectations of this theory are congruent with the outcomes for three parties: Argentina’s Radical Civic Union (UCR), Bolivia’s Nationalist Revolutionary Movement (MNR), and Chile’s Concertación.

\section{Party Brands, Partisanship, and Party Breakdown}

Why did some parties in Latin America break down whereas others, even within the same country, did not? And why have partisan attachments for some Latin American parties eroded 
precipitously in recent decades? Party attachments are group identities, akin to the attachments people form to social groups. They are based on the stereotypes people have about each group. People have an idea about what the prototypical poor person looks like, or how the prototypical banker behaves, and they categorize themselves into group identities by comparing themselves to the group prototype. Individuals identify as a poor person or a banker if they think they resemble, or fit, that prototype (Hogg et al. 1995, Turner et al. 1987). And they also feel closest to a group when they think other groups' prototypes look very different from them, a concept social psychologists call comparative fit (Hogg et al. 2004, Turner 1999).

We can think of these prototypes as representing points on a continuum. For some, class may be the important dimension of political identity. Some parties will be seen as pro-poor, whereas others are seen as favoring the interests of the affluent. In many instances, that class dimension correlates highly with the standard left-right ideological dimension that orients politics in much of the world (Huber and Inglehart 1995, Lijphart 1994). Parties that pursue redistribution to the poor will be seen as representing the poor; those that limit regulation on businesses will be seen as favoring the interests of the affluent. In the Latin American context, the most salient political dimension appears to be the economic left-right (e.g., Altman et al. 2009, Colomer and Escatel 2005, Wiesehomeier and Doyle 2012). ${ }^{4}$

As with other social identities, an individual feels closest to the party whose prototype she thinks she most resembles, relative to all other parties (Green et al. 2005). Over the course of their lives, citizens form perceptions of party prototypes based on what they see the parties say and do over time. ${ }^{5}$ They learn what to associate with the prototypical partisan by observing what

\footnotetext{
${ }^{4}$ I focus on the left-right dimension because it tends to be the most salient in Latin America and therefore offers substantial explanatory power. Nevertheless, the left-right need not be the only salient dimension in every case, and future studies could easily apply this theory to a context in which a different dimension matters more.

${ }^{5}$ Recent studies have found clear evidence that voter perceptions indeed respond to party behavior (e.g., Fortunato
} 
politicians say and do, and they use these prototypes to inform their identity. These prototypes comprise what I call a party brand. Individuals repeatedly update their perceptions of parties' brands, incorporating new observations into their prior beliefs about the parties (Achen 1992).

Party brands can also be weak or strong, depending on how precisely citizens can pinpoint them. When people see a party sending clear signals, they develop a clearer image of its prototypical partisan, and the brand becomes stronger. As their uncertainty about the party's position increases, the party appears to be more heterogeneous, perhaps containing multiple prototypes, and the brand becomes diluted.

These learned party brands form the basis of mass attachments. A citizen will feel the greatest affinity with the party whose prototypical partisan she thinks she most resembles, relative to all other parties. As with other social identities, partisan identity is determined partly by the resemblance, or fit, between the individual's self-image and her image of the party prototype. Party attachments, therefore, increase as citizens perceive they more closely fit with the party. Moreover, the more ambiguous the party brand, the weaker that attachment because an individual will perceive less fit with the party prototype.

Crucially, the degree of identification also depends on comparative fit, the degree to which a citizen feels she resembles the prototype of one group and differs from that of another group. Thus, a person will feel most attached to a party when its prototype most resembles her and the prototypes of other parties seem very different.

This conception of partisanship implies that the behaviors of parties can affect mass attachments (Lupu 2013). In particular, parties can dilute their brands through inconsistency or convergence. Inconsistency increases citizens' uncertainty about the party brand when parties

and Stevenson 2013, Pope and Woon 2009). 
suffer from internal conflicts (see also Grynaviski 2010). Citizens observe conflicting signals from the party and find themselves more uncertain about the party brand. Inconsistency also confuses citizens when a party shifts its position. They may, particularly in Latin America, observe a party they thought was statist suddenly support free-market economic policies (Stokes 2001). ${ }^{6}$

Party brands will also dilute when parties converge (e.g., Lupu 2015b). As they do, citizens become unable to distinguish one party brand from another. ${ }^{7}$ They may observe that different party brands are effectively indistinguishable because elites from different parties support the same policies. Or they may see different parties entering into formal or informal alliances, signals that they are willing to agree on a political agenda (Fortunato and Stevenson 2013). Even when people are certain about two party brands, their substitutability means that citizens fail to form strong attachments with either party.

Partisanship thus erodes in response to party inconsistency and convergence. But the erosion of partisanship also has electoral implications. Voters evaluate parties both in terms their partisan attachments and in terms of performance. As voters become more attached to a party, they will forgive bad performance. But as they become less attached, performance will become an increasingly important determinant of vote choice (Kayser and Wlezien 2011). Party

\footnotetext{
${ }^{6}$ Kitschelt and Wilkinson (2007) suggest that parties lose votes when they are inconsistent. That contrasts with evidence that voters favor ambiguous candidates (Tomz and Van Houweling 2009) and that economic policy shifts sometimes get rewarded electorally (Stokes 2001, Tavits 2007). Still, my focus here is on partisanship, not vote choice. I argue that policy shifts blur party brands and weaken partisanship, even if they sometimes also increase electoral support.

${ }^{7}$ Morgan (2011) similarly highlights the effect of interparty agreements, along with bad performance, on partysystem collapse. Her argument focuses on formal alliances and vote choice, whereas I highlight the effect of interparty convergence of varying kinds on mass partisanship. By distinguishing partisanship from vote choice, my theory explains instances of party convergence eroding partisanship that do not lead to party collapse.
} 
breakdown, therefore, occurs when two conditions are met: (1) the party's brand is diluted, leading partisan attachments to erode, and (2) the party performs poorly in office.

Partisan attachments eroded in Latin America because of growing confusion among citizens about party brands, or what a party stands for. Few established parties in Latin America had the strong, consistent brands of many Western European parties. But in earlier periods, citizens had fairly clear notions about what it meant to be a Peronist in Argentina or an aprista in Peru. That changed when incumbents were confronted with the economic crises and international policy consensus of the 1980s and 1990s.

The debt crisis that swept the region beginning in 1982 raised borrowing costs and forced governments to either cut spending or increase inflation. The Washington Consensus that emerged by the 1990s among economic policy makers focused international attention on lowering debt levels, retrenching governments, and opening domestic markets. As a result, politicians across the region knew that they risked inflationary crises, massive capital flight, and debt default if they did not adopt economic reforms. The new economic circumstances posed a particular challenge to established parties of the left, which traditionally espoused precisely the kinds of economic interventions threatened by the new economic constraints. So politicians from leftist parties across the region implemented market-oriented economic policies that were inconsistent with their party’s statist and labor-based brands. Doing so regularly provoked intense internal conflicts and often required forming surprising alliances with traditional rivals on the right. ${ }^{8}$ That inconsistency and convergence with competitors eroded partisan attachments

\footnotetext{
${ }^{8}$ I take these actions by parties as exogenous here. This seems reasonable: in this period, exogenous international conditions generated electoral incentives and induced presidents to take actions that dilute their party brand, like policy switches (Burgess and Levitsky 2003, Stokes 2001). Elsewhere I specify the conditions under which political elites choose to take these actions (Lupu 2016). Note, though, that brand dilution need not be electorally damaging in the short-term. Brand dilution only makes parties more susceptible to valence evaluations; as long as those evaluations are not bad, brand dilution may not hurt parties at the polls.
} 
and made parties susceptible to voters' short-term valence evaluations. Voters who now had no party attachments deserted incumbent parties when they performed poorly, causing established parties to collapse.

In previous work, I focused on exogenous economic shocks that hit incumbent parties after their brands had been diluted and their partisan base eroded (Lupu 2014, 2016). In this chapter, I expand the operational definition of performance to include social conflict. My theory suggests that when voters do not identify with a particular political party, they will give more weight to valence evaluations. The most widely-studied valence issue is economic performance, but we know that voters also care about other valence issues: they prefer clean government, competence, and social peace (Stokes 1992). This chapter thus expands and builds upon my prior theoretical framework. ${ }^{9}$

\section{Evidence from Three Cases}

If party brands matter in this way, we should observe their effects on both political attitudes and voter behavior. In the realm of attitudes, we would expect to see party inconsistency and convergence weaken voters’ partisan attachments. When looking at voter behavior, we should see the combination of brand dilution and bad performance, broadly defined, lead to party breakdown.

I examine both implications by comparing three very different parties from three very different country contexts. These case studies explore the degree to which party brands help to explain the deinstitutionalization of party systems in the region. My aim is not to select cases

\footnotetext{
${ }^{9}$ Note that my theory focuses on incumbent parties. Although one could potentially extend it by theorizing how voters form valence evaluations about non-incumbent parties, the current theory does not explain cases in which parties collapse while in opposition.
} 
that hold constant confounding variables or address alternative explanations, something I have done elsewhere (Lupu 2016). In this chapter, I use George and Bennett’s (2005) congruence method to evaluate how consistent the theory is with the actual outcomes in a varied set of cases. Inevitably, both large- $\mathrm{N}$ analyses and small-N case studies beg questions about how well the theory fits other cases. This chapter takes up precisely those questions.

Since my goal here is not to engage in controlled comparisons across cases, I selected three cases that were representative of the deinstitutionalization we have seen in Latin America in the period covered by this volume (see Mainwaring and Bizzarro Neto, this volume): party collapse as part of system-wide collapse (Bolivia’s MNR), individual party collapse (Argentina’s UCR), and partisan erosion (Chile’s Concertación). ${ }^{10}$ This approach - which follows "typical case” selection criteria laid out by Gerring (2007) - consciously selects on the dependent variable. But doing so offers a useful contribution about the generality of the theoretical argument to the broader region.

In each case, I use the available individual-level data as well as primary and secondary sources to study whether brand dilution had the effects my theory predicts - partisan erosion and, when combined with bad performance, party breakdown. The electoral trajectories of these parties is shown in Figure 1.

\section{[Figure 1 here]}

Unfortunately, quantitative measures of party behavior that are comparable across countries and over time are not available across these cases. The data that come closest are measures of party convergence based on representative surveys of national legislators conducted

\footnotetext{
${ }^{10}$ Note that in Chile, I focus on a coalition rather than an individual party. This is because of the uniquely institutionalized and stable nature of electoral coalitions in Chile, the result of Chile's peculiar electoral rules (Agüero 2003, Carey 2002). There is also good reason to think that voters' attachments in this context are directed to the coalitions (González et al. 2008), so my discussion will mostly focus on them as the unit of analysis.
} 
by researchers at the University of Salamanca (USAL). These surveys asked legislators to place their own party on a standard left-right dimension. Unfortunately, even these data start in the mid-1990s, after convergence had occurred in Argentina and had begun in Bolivia. Figure 2 reports the average response for the major parties I discuss in Bolivia and Chile. ${ }^{11}$ Both cases demonstrate substantial party convergence. These figures are a useful first step, but we need to better trace the process of convergence - and, to the extent possible, voter perceptions of convergence - in each case to evaluate its congruence with the theoretical expectations.

[Figure 2 here]

\section{Argentina's UCR}

When democracy returned to Argentina in 1983, so too did the two political parties that had contested elections in prior periods of democracy, the UCR and PJ. Since its emergence in the1940s, the PJ drew its electoral support from the rural poor and urban working classes while the UCR was the party of middle and upper classes (Lupu and Stokes 2009). Both parties were heterogeneous, but they nevertheless maintained some brand identities. In a September 1986 survey, nearly 50 percent of survey respondents named the UCR as "the party most bound to privileged sectors”; only 8 percent named the PJ. In contrast, 54 percent thought the PJ offered "the most concrete solutions for neediest sectors," and 73 percent thought it the party that "best represented workers,” compared with 25 percent and 14 percent, respectively, for the UCR. ${ }^{12}$

\footnotetext{
${ }^{11}$ The question asked, "In speaking about politics, it is common to use the terms left and right. This card shows a scale of values that go from left to right [card with 1-10 scale is shown]. At which point would you situate your own party?"

12 Author's calculations from Aresco survey of 1,000 adults in Greater Buenos Aires. The series of questions began, "Could you signal which of the political parties active in the province is . . " The options offered were:

Radicalism, Peronism, PI, UCD, FREPU, or none.
} 
The two parties relied on patronage to maintain internal discipline and to mobilize sectors of the electorate (Calvo and Murillo 2004, Snow 1971). But both also worked assiduously to build and maintain partisan attachments (Lupu and Stokes 2010). Already in 1965, 46 percent of Argentines identified with a party, of which 35 percent identified with the UCR and 30 percent with the PJ (Kirkpatrick 1971: 87). By October 1984, 58 percent of Argentines identified with a party, 52 percent of them with the Peronists and 33 percent with the Radicals (Catterberg 1989: 63).

During the 1980s, both the UCR and PJ maintained those partisan bases by hewing to their traditional brands. Radical president Raúl Alfonsín (1983-89) managed to maintain discipline within the UCR around his various economic proposals. Even some of his most controversial policy initiatives - dealing with the crimes of the 1976-83 military regime achieved near-unanimous UCR support (Mustapic and Goretti 1992). On the other side of the aisle, the PJ demonstrated disciplined opposition to the administration's agenda. Along with its labor backers, the PJ staunchly opposed-and often blocked-Alfonsín’s economic proposals. It rejected both Alfonsín’s initial heterodox economic plan and his later, more market-oriented proposal. PJ-backed unions led a remarkable thirteen general strikes during Alfonsín’s administration, all with the public support and participation of PJ leaders. Anything short of opposition to Radical proposals was seen by Peronists as “illicit unions” (Mustapic and Goretti 1992: 268). ${ }^{13}$ The result was a fairly steady base of Radical partisans: a consistent 20 percent of Argentines identified with the UCR throughout the 1980s.

\footnotetext{
${ }^{13}$ The PJ did suffer an important internal conflict in the 1980s. But unlike the intraparty conflicts that would emerge in the early 1990s, the conflict with the Renovation faction centered on organizational, rather than ideological, issues (Levitsky 2003).
} 
All that changed when the PJ's Carlos Menem took over the presidency amid a hyperinflationary crisis in 1989. Menem was elected on a statist economic platform, promising to reverse the decline of the Argentine economy. But upon taking office, he shocked Argentine voters and his own party by pursuing both a staunchly neoliberal set of economic policies and a series of alliances with anti-Peronist elites and former opponents.

The UCR also found itself unprepared for the Peronist president's policy switch. With Menem offering policies nearly identical to those proposed by Angeloz during the campaign, the UCR found itself in the strange position of agreeing with the Peronist president. Menem immediately opened talks with UCR leaders about forming a unity government. Although a formal pact never materialized, the repeated attempts and negotiations received widespread media coverage and were far more serious than Alfonsín's half-hearted attempts. Particularly noteworthy were two nearly successful rounds of negotiation with Angeloz himself aimed at persuading the former presidential candidate to join Menem's cabinet. As late as November 1991, Menem made serious public overtures for a pact among political parties.

UCR leaders attempted to maintain the nuanced position of opposing some administration proposals while supporting the broad thrust of Menem's economic program. Alfonsín himself oscillated between criticizing the speed of the economic reforms and offering his party's support. In Congress, the UCR proved far less obstructionist than the PJ had been during the 1980s. Then, in late 1993, Alfonsín and Menem emerged from the presidential residence in Olivos to announce their agreement to a pact for the general framework of a constitutional reform. The Pact of Olivos represented renewed convergence by the two parties, with the UCR effectively conceding Menem's reelection. Coverage of the pact promoted the perception that the two parties had become indistinguishable: cartoons, for instance, fused 
Menem and Alfonsín into a single figure. ${ }^{14}$ The convergence of the two parties significantly affected partisan attachments. By October 1995, less than 10 percent of Argentines identified with the UCR. ${ }^{15}$ Still, Menem was reelected on positive public assessments of his stewardship of the economic crisis.

In his second term, the UCR began to reposition itself as a center-left alternative to Menem’s neoliberal PJ. In 1997, it formalized an alliance with the leftwing FREPASO to solidify its anti-neoliberal credentials. FREPASO leaders - themselves defectors from the ranks of the PJ - had emphasized the social costs of neoliberal policies on unemployment, poverty, and inequality, and promised to work to address them. In 1999, the Alliance for Work, Justice, and Education (Alianza) successfully elected the UCR’s Fernando de la Rúa president with FREPASO leader Carlos Álvarez as vice president.

But the Alianza’s electoral success did not translate into successful governing. Relations between the two parties strained quickly. On taking office, Economy Minister José Luis Machinea announced tax increases and austerity measures, including cuts in education and social services, the very areas the Alianza had promised to reinforce. The cuts were deeply criticized by FREPASO legislators and cabinet members. Although the Alianza held a majority in the lower chamber of Congress, the dissent of some FREPASO legislators made it difficult for the administration to pass legislation (Jones and Hwang 2005). So De la Rúa resorted to governing by decree (Mustapic 2005) and ceased consulting with Álvarez and FREPASO. Hostilities

\footnotetext{
${ }^{14}$ Clarín, December 13, 1993.

${ }^{15}$ Author's calculations from a national survey of 1,811 adults conducted by Romer \& Associates. The question asked, "With which party do you identify more? Which party best represents your way of thinking?” This wording likely even overstates actual identification.
} 
between the coalition partners came to a head in June 2000, when reports that the administration had bribed senators led Álvarez to resign suddenly.

In early 2001, De la Rúa appointed a neoliberal Radical as Minister of the Economy and announced new spending cuts to education, a direct contradiction of one of the foundations of FREPASO’s program. The reaction from FREPASO and De la Rúa's own UCR was swift. Party leaders spoke out against the administration with unrestrained vehemence. Three Radical cabinet members resigned in protest. Alfonsín soon added his own criticism of. Within weeks, the Radical president decided he could no longer govern with FREPASO and began to rely instead on the architect of Menem's neoliberal reforms, Domingo Cavallo, and his backers in the PJ. One prominent UCR deputy, Elisa Carrió, denounced fellow Radicals who voted for Cavallo's proposals as "traitors;" ${ }^{16}$ she soon left the UCR to form a new party.

The Radical party brand had become so meaningless and so indistinguishable from the PJ that politicians now preferred to form their own parties. In the ensuing months, other FRPASO and UCR politicians followed Carrió. With the credibility of the De la Rúa administration in decline, economic uncertainty soared. By the end of 2001, economic pressures forced De la Rúa to default on Argentina's loans and resign the presidency (Levitsky and Murillo 2003).

De la Rúa's resignation forced the PJ-controlled Senate to choose his successor. After some false starts, the Senate appointed Eduardo Duhalde, the former vice president who had lost the 1999 election to De la Rúa. His selection received the support of the PJ, UCR, and FREPASO. Duhalde called for a government of national unity and negotiated with both PJ and UCR governors, promising not to run in the 2003 elections. Two Radicals and one FREPASO leader joined his cabinet. And both the UCR and FREPASO supported granting Duhalde

${ }^{16}$ La Nación, March 26, 2001. 
emergency decree powers, something they had denied De la Rúa. During his seventeen months in office, Duhalde repeatedly relied on UCR and FREPASO support in Congress. FREPASO even joined the administration's legislative bloc.

By the time of the 2003 election, Argentina's political parties were in disarray. The UCR's inconsistencies and internal conflicts during the De la Rúa administration had so diluted its brand that few voters still identified with the party. In the months leading up to the election, less than 5 percent of Argentines said they identified with the UCR. ${ }^{17}$ At the same time, perceptions of De la Rúa’s economic performance were dismal. In a November 2001 survey, fewer than 3 percent of Argentines said the De la Rúa administration was managing things well or very well. ${ }^{18}$

Blamed for disastrous performance in office and lacking a partisan base, the UCR was doomed. A party that only four years earlier had garnered 48 percent of the vote now attracted a mere 2 percent. ${ }^{19}$ The 2003 election thus dealt the death blow to the UCR, which has since been uncompetitive in national elections. The Argentine party system had gone from a stable twoparty system to a fragmented system of competing personalities with no clear party brands. Even the PJ, which muddled through its own brand's dilution during the economic crisis, would need to reconstruct its brand to recover the level of partisan attachments it had once enjoyed.

\footnotetext{
${ }^{17}$ Author's calculation from various surveys of adults in Greater Buenos Aires conducted by Carlos Fara \& Associates.

${ }^{18}$ Author's calculations from a national survey of 1,200 adults conducted by Mora y Araujo \& Associates. The question asked, "How do you believe the national government is managing things?"

${ }^{19}$ The UCR had performed dismally before, in 1989. But back then, it still had a loyal base of partisans supporting its candidate. Only in 2003, when bad performance was combined with brand dilution that eroded voter attachments, did breakdown occur.
} 


\section{Bolivia's MNR}

Bolivia’s transition to democracy was one of the most chaotic in the region (Dunkerley 1984), the result of an economic crisis that led to labor unrest and peasant mobilization against the military regime. The result was a temporarily stable three-party system (Gamarra 2003). On the left, the Revolutionary Left Movement (MIR) has formed in 1970 to unite the disparate leftist and labor groups across the country. In the center was the historic MNR, borne of the 1952 popular revolution that had incorporated labor groups and mobilized rural peasants in favor of land reform. The political and economic right, led by the military dictator Hugo Bánzer, formed the Nationalist Democratic Action party (ADN).

For both institutional and political reasons, the parties needed to join forces in order to govern. Bolivia's constitution provided that if no candidate received a majority of the vote, Congress would select the president. In a stable three-party system, no single candidate attracted an electoral majority until 2005, so the parties in Congress would need to form coalitions to select a president (Gamarra 1997). And since no party held a majority in Congress, those alliances would also be designed to persist so that the selected president could successfully pursue a legislative agenda.

Initially, Bolivia’s coalition governments were broadly consistent with the historical traditions and origins of the three parties. In 1980, the centrist MNR and leftist MIR coalesced behind the candidacy of Hernán Siles Zuazo, a leftist defector from the MNR, in an effort to prevent Bánzer, ADN’s candidate, from retaking office. ${ }^{20}$ Consistent with his campaign promises, Siles Zuazo pursued a series of economic policies aimed at stemming the government's building export and debt crises. But in the midst of hyperinflation and massive

\footnotetext{
${ }^{20}$ A subsequent military coup prevented Siles Zuazo from taking office until 1982 (Whitehead 1986).
} 
popular protests, he agreed to step down ahead of schedule. As in 1980, the MNR and MIR coalesced to select the new president, the MNR's Víctor Paz Estenssoro, even though he had come in second (to Bánzer) in the election.

Rather than govern with the MIR, Paz Estenssoro decided to ally his administration with the rightwing $\mathrm{ADN}$ and pursue the market-oriented economic reforms being prescribed by international financial institutions (Malloy 1991). Through an informal "Pact for Democracy," Paz Estenssoro provided Bánzer’s party with access to government jobs in exchange for legislative support (Gamarra 1994). The new administration reversed many of the economic policies of Siles Zuazo - and some of Paz Estenssoro’s own campaign promises - but the threeparty system made a center-right coalition just as palatable as a center-left one. Indeed, the ability of the parties to successfully select and support a president seemed to many observers to be a sign of the system’s consolidation (Malloy 1991, Mayorga 1997, Whitehead 2001).

It was not until 1989 that the Bolivian parties began to engage in what Slater and Simmons call "promiscuous powersharing” (Slater and Simmons 2013). Following a fierce election campaign, the leftwing MIR and rightwing ADN agreed to jointly select the third-place MIR candidate Jaime Paz Zamora as president. The alliance between the two diametrically opposed parties, known as the "Patriotic Alliance," and the selection of the third-place candidate shocked voters (Gamarra 1994). ${ }^{21}$ Paz Zamora, moreover, abandoned his party’s core constituency of workers and peasants, instead adopting the Paz Estenssoro administration's neoliberal economic agenda (Conaghan and Malloy 1994). As a result, it soon became clear to

\footnotetext{
${ }^{21}$ Gamarra and Malloy (1995) recount a joke circulating in the aftermath of the 1989 election: "Before the election the three candidates visited the Virgen de Urkupiña, who offered them one wish each. [MNR candidate] Sánchez de Lozada wished to win the elections; Paz Zamora, to be president; and Bánzer, to run the country. The generous Virgin granted all three wishes” (413).
} 
voters that the party of the left and the party of the right were in fact quite similar in terms of the kinds of policies they would be willing to support (Centellas 2007).

For those who still held out hope of differentiable party brands, the parties cemented their convergence over the course of the ensuing decade. As the economy grew and inflation stabilized, the three parties continued to alternate in an array of alliances. As fewer and fewer Bolivians identified with the parties, the volatility of the vote increased. The three historic parties also lost electoral ground to emerging new parties, some of which had started to build distinguishable brands and partisan followings. But even many of these parties, eager for the resources of office, entered into the governing coalitions. A notable exception was the Movement toward Socialism (MAS).

In 1993, ADN and MIR cemented their coalition by putting forward only one presidential candidate under the banner of the Patriotic Alliance. But MNR’s Gonzálo Sánchez de Lozada, who for the second time came in first place in terms of votes, forged a coalition of small parties for a congressional majority. He even offered the vice presidency to the leader of the Revolutionary Liberation Movement Tupac Katari (MRTKL), an emerging indigenous party. And he passed several electoral and political reforms not only to deepen democratic consolidation and market reforms (Grindle 2003), but also to forestall further deinstitutionalization and protect the electoral strength of his party (O'Neill 2005). But the reforms could not undo the fact that all three parties - MIR, ADN, and MNR - had espoused the same basic economic agenda. Like both his predecessors, Paz Zamora and Paz Estenssoro, Sánchez de Lozada continued to implement market-oriented economic reforms.

Following Sánchez de Lozada’s lead, MIR and ADN similarly cobbled together an alliance of small parties - including some of the parties that had backed Sánchez de Lozada - to 
bring Bánzer himself back to power in 1997. The so-called "mega-coalition” showed the Bolivian public that the parties had not only converged substantially on the neoliberal economic agenda, they were also now pursuing many of the same economic policies put forward by the pre-1982 military regime. By 2001, Bánzer was 75 years old and his health was declining precipitously. He resigned, passing the presidency, and leadership of the ADN, to Jorge Quiroga, and died shortly thereafter.

With protests emerging in the countryside against neoliberalism (Arce and Rice 2009, Barr 2005), Sánchez de Lozada convinced MIR and Bánzer’s coalition partners to back him for a second presidency in 2002 (Singer 2004). The historic parties, having all converged on centerright economic policies, were staging a last-ditch effort to keep the runner-up, leftwing Evo Morales and his MAS out of national office (Van Cott 2003). ${ }^{22}$ The gambit worked temporarily, until MAS-led protests and marches on the capital destabilized the country (Gingerich 2009, Mayorga 2005). The “Gas War,” as the social conflict over Sánchez de Lozada’s plans to export natural gas through Chile became known, came to a head in 2003 when the countrywide protests and roadblocks were met with violent government repression. After 60 protesters were killed by government forces, Sánchez de Lozada resigned and fled the country. By the time of the scheduled 2005 elections, the MNR had collapsed; its candidate received a paltry 6 percent of the vote.

The MNR had not just severely diluted its brand by converging with its rivals again and again, it had also failed to quell the extraordinary social unrest. Like the UCR in Argentina, it likely had no partisan base to rely on at a time when voters uniformly blamed the party for

\footnotetext{
${ }^{22}$ This gambit is reminiscent of the last-ditch effort in 1998 by the two historic parties in Venezuela to coalesce around a single candidate in order to forestall the election of Hugo Chávez.
} 
dismal performance. ${ }^{23}$ In Bolivia, that dismal performance came in terms of the government's incapacity to maintain social order and its violent response to the protests, whereas in Argentina it centered on the combination of a deep economic crisis and the De la Rúa government's violent handling of subsequent protests.

\section{Chile’s Concertación}

In the 1990s, the Chilean party system was widely regarded as being among the most stable and most institutionalized in Latin America (e.g., Dix 1992, Mainwaring and Scully 1995). And yet, individual attachments to the country's political parties have eroded since the return to democracy in 1990. Despite the persistence of its historic political parties and continued competition among two main political coalitions (Valenzuela and Scully 1997), levels of voter partisanship in Chile are today among the lowest in the region (Lupu 2015a). ${ }^{24}$ The reason has partly to do with the behaviors of those coalitions over the course of the 1990s and 2000s.

When the government of General Augusto Pinochet organized a plebiscite on his continuation in office, Chile's historic parties of the left and center joined forces in the campaign for democratization, eventually forming the Concertación (Concertación de Partidos por la Democracia) (Siavelis 2009). The left and right in Chile had fought vehement political and military battles throughout the 1960s and 1970s, and polarization between the two sides was seen as an important contributor to the breakdown of democracy (Valenzuela 1978). Even during the Pinochet era, leftist leaders repeatedly failed to compromise and join forces with the centrist Christian Democrats (Siavelis 2014).

\footnotetext{
${ }^{23}$ Data on mass partisanship is not publicly available for this period in Bolivia, so in this case I am unable to document the intermediate step of partisan erosion between party convergence and breakdown.

${ }^{24}$ See also Luna and Altman (2011).
} 
After winning the plebiscite, the Concertación then succeeded in getting its presidential candidate, the Christian Democrat Patricio Aylwin elected to the presidency. The centrist Aylwin oversaw significant increases in social spending, but without dismantling the neoliberal foundations of macroeconomic stability put in place by Pinochet and his 'Chicago Boys.' More radical socioeconomic or political reforms were opposed by many Christian Democrats within the coalition and would also have proved difficult to legislate given the system's "authoritarian enclaves,” institutions like lifetime or designated Senate appointments inserted in the 1980 constitution by Pinochet to perpetuate the power of the regime (Siavelis 2000). In the posttransition context, Aylwin chose to pursue policies like tax and judicial reform that would gain support from segments of the rightwing Alliance for Chile (Alianza) rather than provoke hostility (Boylan 1996, Fuentes 2014). His successor, Eduardo Frei, a fellow Christian Democrat, took a similar tack of centrist compromise. Indeed, ideological questions were almost completely absent from the 1993 presidential campaign (Angell 2007). By the end of the 1990s, the Concertación was widely viewed as a very moderate center-left coalition (Agüero 2003), ${ }^{25}$ in stark contrast to the once-radical positions held by some of its member parties (Portes 1970).

Throughout this period, the opposition Alianza found it difficult to soften its hardline rightwing image and association with the Pinochet regime. It was particularly hampered by conflicts between the coalition's two main parties and the fact that Pinochet himself remained head of the military (Navia and Godoy 2014). But his resignation and arrest in 1998 empowered those within the Alianza who wanted to moderate the coalition’s stances. During the 1999 presidential campaign, the Alianza’s Joaquín Lavín, associated with the hardline right wing of

\footnotetext{
${ }^{25}$ The coalition's electoral losses in 1997 were widely interpreted as resulting from defections on the left by sectors unhappy with the Concertación’s moderate economic stances (Posner 1999).
} 
his coalition, moderated many of his positions and came closer than expected to winning the election (Silva 2001). As Fontaine Talavera (2000) notes, "what began as merely tactical postures ended up becoming commitments” (73).

Those commitments became even more pronounced when Sebastián Piñera became an Alianza candidate in opposition to Lavín in the presidential election of 2005. Unlike prior Alianza candidates, Piñera positioned himself as a moderate "Christian humanist," appealing to centrist supporters of the Christian Democratic Party (PDC), a member of the Concertación (Morales Quiroga 2008). Unlike Lavín, he had no ties to the military regime of Augusto Pinochet and its neoliberal economic policies. ${ }^{26}$ And he promised to govern not only with the right but in a 'New Coalition' with the center, a promise he sought to make more concrete by including former members of the PDC on his campaign team (Gamboa and Segovia 2006). The result, notes Angell (2007), was that the "emphasis of both candidates of the right on poverty and exclusion seemed to represent a shift from their free-market economic doctrine to one resembling the left of the Concertación” (119).

By the end of the 2000s, the differences between the Concertación and Alianza on major economic issues had declined substantially. Indeed, by 2009, those who still identified with one or the other coalition scarcely differed in terms of their preferences over socioeconomic policies (Castillo et al. 2013). Consistent with my expectations, this convergence among the parties also eroded mass partisanship. The black lines in Figure 3 track the longitudinal trends in voter attachments to the Concertación and Alianza over the two decades of the current democratic period. ${ }^{27}$ The trends show some decline in attachments to the Concertación during the 1990s,

\footnotetext{
${ }^{26}$ In fact, Piñera had publicly voiced his intention to vote against Pinochet in 1988.

${ }^{27}$ The data come from nationally representative surveys conducted by the Centro de Estudios Públicos. The specific studies used here were conducted around the presidential elections of 1989, 1993, 1999, 2005, and 2009. Specifically, the surveys were conducted in May-June 1990 (\#14), November-December 1994 (\#29), December
} 
followed by a second decline in the latter half of the 2000s. The Alianza appears to gain partisans during the 1990s, but suffers a similar decline in the latter 2000s.

[Figure 3 here]

The USAL survey data in Figure 1 show some convergence between the PDC and RN during some of this period, but it only goes up to 2006. Moreover, those surveys ask only about individual parties, not about the coalitions. As an alternative, the red line in Figure 3 plots a different measure of the ideological distance between the Concertación and Alianza over the same period. To construct this distance, I use a measure of party positions developed by Gamboa et al. (2013) using the electoral manifestos of the coalitions. They follow the methods employed by the Comparative Manifesto Project for mapping party positions in advanced democracies on a left-right ideological scale (Budge et al. 2001). ${ }^{28}$ Although electoral manifestos are primarily internal party documents that few voters ever read, they may reflect the general positions of the parties and could therefore serve as reliable proxies of relative party positions. ${ }^{29}$

Taken together, the two trends - convergence between the two coalitions and declining mass partisanship - seem to correlate as expected. As the Concertación shifted to the center during the 1990s and the Alianza did the same in the 2000s, mass attachments to both coalitions declined. This is consistent with the notion that as these coalitions diluted their brands by

1997-January 1998 (\#35), October-November 1999 (\#38), June-July 2006 (\#52), and June-July 2010 (\#62).

${ }^{28}$ There is some debate among Chile scholars about whether the salient dimension of political competition in Chile is left-right ideology or a democratic-authoritarian dimension held over from historical support or opposition for the Pinochet regime (Alcántara Sáez and Luna 2004, Alvarez and Katz 2009, Tironi and Agüero 1999, Torcal and Mainwaring 2003, Valenzuela 1999).

${ }^{29}$ There is considerable debate about the appropriateness of using manifesto data to measure party positions (e.g., Benoit and Laver 2006). Although I recognize the limitations of these data, I consider them a reasonable choice given that few other options (such as reliable expert surveys over time) are available. 
diminishing the differences between them, fewer and fewer Chileans formed long-standing attachments to one over the other. Party convergence in Chile also appears to have weakened other political identities (Bargsted and Somma 2016), as it has in other contexts (Evans and Tilley 2012).

Like the UCR in Argentina and MNR in Bolivia, though to a lesser degree, Chile's Concertación converged with its competitor over the course of the 1990s and 2000s. And as in the other cases, this convergence eroded mass attachments to the coalition. But unlike the UCR and MNR, the Concertación remains a powerful electoral force in Chile. In part, the convergence of the Chilean coalitions has not been as dramatic - or as complete - as that of the traditional parties in Argentina or Bolivia, as Figure 1 shows. The Concertación, therefore, maintains, a significant, though diminished, base of partisan supporters to this day. Moreover, the Concertación’s performance in office has so far remained good, or average at worst. ${ }^{30}$ Although its diminished partisan base has made it more susceptible to the performance evaluations of voters, it has yet to enter an election in which these evaluations are predominantly negative, as the UCR did in 2003 and the MNR did in 2005.

\section{Party Brands and Party-System Institutionalization}

How parties behave affects how voters perceive them and, in turn, the attachments they will form. When parties are inconsistent, sending mixed signals to voters or shifting on issues voters care about, voters become uncertain about what the party stands for, and who it represents. Similarly, when parties converge, by allying with supposed rivals or simply by converging with

\footnotetext{
${ }^{30}$ Looking at all 72 of the national surveys conducted by Chile’s Centro de Estudios Públicos since 1989, one finds that the only time in which a majority of voters held negative (as opposed to positive or neutral) evaluations of the economy was briefly at the beginning of Ricardo Lagos's term. But even those negative evaluations had dissipated by the time presidential elections were held again in 2005.
} 
major competitors, voters will feel less affinity with one over the other. As they see fewer and fewer differences in what parties stand for and the types of voters they represent, voters will be less likely to form strong partisan attachments.

In Argentina, the UCR's inconsistency and its dramatic convergence with its historic rival, the PJ, severely eroded its partisan base. By the early 2000s, relatively few Argentines called themselves Radicals. In Bolivia, the three historic parties all converged in the midst of a deep economic crisis and severe international constraints. The MNR, once a deeply-rooted fulcrum of Bolivian politics, no longer seemed to represent its peasant base. Though far less dramatically, even the stable Chilean coalitions have steadily moved closer on major economic issues, eroding voters’ attachments to them.

These erosions are in and of themselves problematic for the institutionalization of these party systems. After all, stable bases of support are an important element of party system institutionalization (Mainwaring and Scully 1995), and partisanship is a common way in which parties form stable bases. But in Argentina and Bolivia, partisan erosion also deinstitutionalized the party systems by contributing to the rapid collapse of major parties. The combination of an eroded partisan base and bad incumbent performance - the deep economic crisis in Argentina in 2001-2002 and the destabilizing social conflicts in Bolivia in 2003 - caused two historic parties to go from winning the presidency to electoral irrelevance in a single term. Their collapse, and the rapidity with which it occurred, destabilized these party systems. Bolivia's party system was already only weakly institutionalized, but whatever stability it had seen in the 1980s and 1990s was replaced by a fragmented and fluid party system. Only the MAS, the one party that had maintained a consistent and distinguishable brand, survived unscathed; indeed, it benefited enormously from the fragmentation of its opposition. Following the collapse of the UCR, 
Argentina's party system also fragmented dramatically (see Gervasoni, this volume). The political space formerly occupied by the UCR yielded to a dizzying array of parties, and the PJ, now effectively unchallenged, splintered. Party collapse rolled back whatever institutionalization the Bolivian party system had achieved and completely deinstitutionalized the once-stable Argentine one. Although Chile's party system has avoided these fates so far, further convergence among the coalitions would make it susceptible to these kinds of outcomes if an economic or social crisis arises.

What these cases suggest - and there are others like them across the region - is that two factors have played important roles in the deinstitutionalization of party systems across Latin America. The first is the particularly constrained economic policy environment in which many of these countries found themselves during the 1980s and 1990s, precisely during the consolidation of electoral democracies in much of the region. Because political leaders were severely constrained in the kinds of economic policies they could pursue, many had little choice but to dilute their parties' brands. ${ }^{31}$ The second factor these cases, and others like them, highlight is the economic vulnerability of these developing democracies. Economic crises like those suffered in many countries in the region in the late 1990s and early 2000s led to the collapse of major parties that had been made vulnerable by brand dilution. Stronger economies less susceptible to crisis might have muddled through a period of diluted party brands and thin partisan bases to reconstruct distinguishable party brands and rebuild party attachments. What is also clear from these cases is that in such contexts, even the most institutionalized party systems cannot be taken for granted.

\footnotetext{
${ }^{31}$ One the one hand, international financial institutions often imposed economic policies on national leaders in this period. On the other hand, the international economic environment at the time also made pursuing market-oriented economic policies vastly more electorally attractive (in that they were far more likely to generate positive economic outcomes in the short term).
} 
More broadly, the emphasis here on party brands implies an important normative role for partisan conflict. Political moderation often seems normatively appealing; where extremism is dogmatic and polarization is conflictual, moderation is pragmatic and consensual. Hence the perennial calls in the United States for "bipartisanship.” But if partisanship is necessary for the institutionalization of a party system, then voters need to be offered meaningfully different party choices rather than consensus. Too much polarization may well be destabilizing - as many scholars have argued (e.g., Sartori 1976; Valenzuela 1978) - but too little may be just as harmful. 


\section{References}

Achen, Christopher H. 1992. "Social Psychology, Demographic Variables, and Linear Regression: Breaking the Iron Triangle in Voting Research.” Political Behavior 14 (3): 195-211.

Agüero, Felipe. 2003. “Chile: Unfinished Transition and Increased Political Competition.” In Constructing Democratic Governance in Latin America, eds. Jorge I. Domínguez and Michael Shifter, 2nd ed. Baltimore: The Johns Hopkins University Press. 292-320.

Alcántara Sáez, Manuel, and Juan Pablo Luna. 2004. “Ideología y competencia partidaria en dos post-transiciones: Chile y Uruguay en perspectiva comparada.” Revista de Ciencia Política 24 (1): 128-68.

Altman, David, Juan Pablo Luna, Rafael Piñeiro, and Sergio Toro. 2009. "Partidos y sistemas de partidos en América Latina: Aproximaciones desde la encuesta a expertos 2009.” Revista de Ciencia Política 29 (3): 775-98.

Alvarez, Ramon Michael, and Gabriel Katz. 2009. "Structural cleavages, electoral competition and partisan divide: A Bayesian multinomial probit analysis of Chile’s 2005 election.” Electoral Studies 28 (2): 177-89.

Angell, Alan. 2007. Democracy after Pinochet: Politics, Parties and Elections in Chile. Washington, D.C.: Brookings Institution Press.

Arce, Moisés, and Roberta Rice. 2009. “Societal Protest in Post-Stabilization Bolivia.” Latin American Research Review 44 (1): 88-101.

Bargsted, Matías A., and Nicolás M. Somma. 2016. "Social cleavages and political dealignment in contemporary Chile, 1995-2009.” Party Politics 22 (1): 105-24.

Barr, Robert R. 2005. “Bolivia: Another Uncompleted Revolution.” Latin American Politics and Society 47 (3): 69-90.

Benoit, Kenneth, and Michael Laver. 2006. Party Policy in Modern Democracies. New York: Routledge.

Benton, Allyson Lucinda. "Patronage Games: Economic Reform, Political Institutions, and the Decline of Party Stability in Latin America.” Ph.D. Dissertation, University of California, Los Angeles, 2001.

Boylan, Delia M. 1996. "Taxation and Transition: The Politics of the 1990 Chilean Tax Reform.” Latin American Research Review 31 (1): 7-31.

Budge, Ian, Hans-Dieter Klingemann, Adreas Volkens, Judith Bara, and Eric Tanabaum. 2001. Mapping Policy Preferences: Estimates for Parties, Electors, and Governments, 1945- 
1998. New York: Oxford University Press.

Burgess, Katrina. 1999. "Loyalty Dilemmas and Market Reform: Party-Union Alliances under Stress in Mexico, Spain, and Venezuela.” World Politics 52 (1): 105-34.

Burgess, Katrina, and Steven Levitsky. 2003. "Explaining Populist Party Adaptation in Latin America: Environmental and Organizational Determinants of Party Change in Argentina, Mexico, Peru, and Venezuela.” Comparative Political Studies 36 (8): 881-911.

Calvo, Ernesto, and María Victoria Murillo. 2004. "Who Delivers? Partisan Clients in the Argentine Electoral Market.” American Journal of Political Science 48 (4): 742-57.

Cameron, Maxwell A. 1994. Democracy and Authoritarianism in Peru: Political Coalitions and Social Change. New York: St. Martin's Press.

Campello, Daniela. 2014. "The Politics of Financial Booms and Crises: Evidence from Latin America.” Comparative Political Studies 47 (2): 260-86.

Carey, John M. 2002. "Parties and Coalitions in Chile in the 1990s." In Legislative Politics in Latin America, eds. Scott Morgenstern and Benito Nacif. Cambridge: Cambridge University Press. 222-53.

Castillo, Juan Carlos, Ignacio Madero-Cabib, and Alan Salamovich. 2013. "Clivajes partidarios y cambios en preferencias distributivas en Chile.” Revista de Ciencia Política 33 (2): 469-88.

Catterberg, Edgardo. 1989. Los argentinos frente a la política: Cultura política y opinión pública en la transición argentina a la democracia. Buenos Aires: Planeta.

Centellas, Miguel. 2007. "Democracy on Stilts: Bolivia’s Democracy from Stability to Crisis.” PhD Dissertation, Western Michigan University.

Centellas, Miguel. 2009. "Electoral Reform, Regional Cleavages, and Party System Stability in Bolivia.” Journal of Politics in Latin America 1 (2): 115-31.

Colomer, Josep M., and Luis E. Escatel. 2005. "La dimensión izquierda-derecha en América Latina.” Desarrollo Económico 45 (177): 123-36.

Conaghan, Catherine M., and James M. Malloy. 1994. Unsettling Statecraft: Democracy and Neoliberalism in the Central Andes. Pittsburgh, PA: University of Pittsburgh Press.

Coppedge, Michael. 2005. "Explaining Democratic Deterioration in Venezuela through Nested Inference." In The Third Wave of Democratization in Latin America: Advances and Setbacks, eds. Frances Hagopian and Scott Mainwaring. Cambridge: Cambridge University Press. 289-316. 
Cox, Gary W. 1997. Making Votes Count: Strategic Coordination in the World's Electoral Systems. Cambridge: Cambridge University Press.

Dalton, Russell J., Scott C. Flanagan, and Paul Allen Beck, eds. 1984. Electoral Change in Advanced Industrial Democracies: Realignment or Dealignment? Princeton: Princeton University Press.

Dietz, Henry, and David Myers. 2007. "From Thaw to Deluge: The Process of Abrupt Party System Collapse.” Latin American Politics and Society 49 (2): 59-85.

Dix, Robert H. 1992. "Democratization and the Institutionalization of Latin American Political Parties.” Comparative Political Studies 24 (4): 488-511.

Dunkerley, James. 1984. Rebellion in the veins: Political struggle in Bolivia, 1952-82. London: Verso.

Eaton, Kent, and J. Tyler Dickovic. 2004. “The Politics of Re-Centralization in Argentina and Brazil.” Latin American Research Review 39 (1): 90-122.

Evans, Geoffrey, and James Tilley. 2012. “How Parties Shape Class Politics: Explaining the Decline of the Class Basis of Party Support.” British Journal of Political Science 42 (1): 137-61.

Fontaine Talavera, Arturo. 2000. “Chile’s Elections: The New Face of the Right “. Journal of Democracy 11 (2): 70-77.

Fortunato, David, and Randolph T. Stevenson. 2013. "Perceptions of Partisan Ideologies: The Effect of Coalition Participation.” American Journal of Political Science 57 (2): 459-77.

Fuentes, Carlos A. 2014. “Democratizing Chile Through Constitutional Reforms.” In Democratic Chile: The Politics and Policies of a Historic Coalition, 1990-2010, eds. Kirsten Sehnbruch and Peter M. Siavelis. Boulder, CO: Lynne Rienner Publishers. 69101.

Gamarra, Eduardo A. 1994. "Crafting Political Support for Stabilization: Political Pacts and the New Economic Policy in Bolivia.” In Democracy, Markets, and Structural Reform in Latin America: Argentina, Bolivia, Brazil, Chile, and Mexico, eds. William C. Smith, Carlos H. Acuña and Eduardo A. Gamarra. New Brunswick: Transaction Publishers. 105-27.

Gamarra, Eduardo A. 1997. "Hybrid Presidentialism and Democratization: The Case of Bolivia.” In Presidentialism and Democracy in Latin America, eds. Scott Mainwaring and Matthew Soberg Shugart. Cambridge: Cambridge University Press. 363-93.

Gamarra, Eduardo A. 2003. “Political Parties Since 1964: The Construction of Bolivia’s Multiparty System.” In Proclaiming Revolution: Bolivia in Comparative Perspective, 
eds. Merilee S. Grindle and Pilar Domingo. London: Institute of Latin American Studies. 289-317.

Gamarra, Eduardo A., and James M. Malloy. 1995. “The Patrimonial Dynamics of Party Politics in Bolivia.” In Building Democratic Institutions: Party Systems in Latin America, eds. Scott Mainwaring and Timothy R. Scully. Stanford, CA: Stanford University Press. 399-433.

Gamboa, Ricardo, Miguel Ángel López, and Jaime Baeza. 2013. “La evolución programática de los partidos chilenos 1970-2009: De la polarización al consenso.” Revista de Ciencia Política 33 (2): 443-67.

Gamboa, Ricardo, and Carolina Segovia. 2006. "Las elecciones presidenciales y parlamentarias en Chile, diciembre 2005 - enero 2006.” Revista de Ciencia Política 26 (1): 84-113.

George, Alexander L., and Andrew Bennett. 2005. Case Studies and Theory Development in the Social Sciences. Cambridge, MA: MIT Press.

Gerring, John. 2007. Case Study Research: Principles and Practice. Cambridge: Cambridge University Press.

Gingerich, Daniel W. 2009. “Corruption and Political Decay: Evidence from Bolivia.” Quarterly Journal of Political Science 4 (1): 1-34.

Golden, Miriam. 2004. “International Economic Sources of Regime Change: How European Integration Undermined Italy’s Postwar Party System.” Comparative Political Studies 37 (10): 1238-74.

González, Roberto, Jorge Manzi, José L. Saiz, Marilynn Brewer, Pablo de Tezanos-Pinto, David Torres, María Teresa Aravena, and Nerea Aldunate. 2008. “Interparty Attitudes in Chile: Coalitions as Superordinate Social Identities.” Political Psychology 29 (1): 93118.

Green, Donald Philip, Bradley Palmquist, and Eric Schickler. 2005. Partisan Hearts and Minds: Political Parties and the Social Identities of Voters. New Haven: Yale University Press.

Grindle, Merilee S. 2003. “Shadowing the Past? Policy Reform in Bolivia, 1985-2003.” In Proclaiming Revolution: Bolivia in Comparative Perspective, eds. Merilee S. Grindle and Pilar Domingo. London: Institute of Latin American Studies. 318-44.

Grynaviski, Jeffrey D. 2010. Partisan Bonds: Political Reputations and Legislative Accountability. Cambridge: Cambridge University Press.

Hogg, Michael A., Dominic Abrams, Sabine Otten, and Steve Hinkle. 2004. “The Social Identity Perspective: Intergroup Relations, Self-Conception, and Small Groups.” Small 
Group Research 35 (3): 246-76.

Hogg, Michael A., Elizabeth A. Hardie, and Katherine J. Reynolds. 1995. "Prototypical similarity, self-categorization, and depersonalized attraction: a perspective on group cohesiveness.” European Journal of Social Psychology 25 (2): 159-77.

Huber, John D., and Ronald Inglehart. 1995. "Expert Interpretations of Party Space and Party Locations in 42 Societies.” Party Politics 1 (1): 73-111.

Jones, Mark P., and Wonjae Hwang. 2005. "Party Government in Presidential Democracies: Extending Cartel Theory Beyond the U.S. Congress.” American Journal of Political Science 49 (2): 267-82.

Kayser, Mark Andreas, and Christopher Wlezien. 2011. "Performance pressure: Patterns of partisanship and the economic vote.” European Journal of Political Research 50 (3): 365-94.

Kenney, Charles D. 2004. Fujimori's Coup and the Breakdown of Democracy in Latin America. Notre Dame, Indiana: University of Notre Dame Press.

Kirkpatrick, Jeane. 1971. Leader and Vanguard in Mass Society: A Study of Peronist Argentina. Cambridge, MA: MIT Press.

Kitschelt, Herbert, and Steven Wilkinson. 2007. "Citizen-politician linkages: an introduction." In Patrons, Clients, and Policies: Patterns of Democratic Accountability and Political Competition, eds. Herbert Kitschelt and Steven Wilkinson. Cambridge: Cambridge University Press. 1-49.

Levitsky, Steven. 2003. Transforming Labor-Based Parties in Latin America: Argentine Peronism in Comparative Perspective. Cambridge: Cambridge University Press.

Levitsky, Steven, and María Victoria Murillo. 2003. “Argentina Weathers the Storm.” Journal of Democracy 14 (4): 152-66.

Levitsky, Steven, and Lucan A. Way. 1998. "Between a Shock and a Hard Place: The Dynamics of Labor-Backed Adjustment in Poland and Argentina." Comparative Politics 30 (2): 171-92.

Lijphart, Arend. 1994. Electoral Systems and Party Systems: A Study of Twenty-Seven Democracies, 1945-1990. New York: Oxford University Press.

Luna, Juan Pablo, and David Altman. 2011. "Uprooted but Stable: Chilean Parties and the Concept of Party System Institutionalization.” Latin American Politics and Society 53 (2): $1-28$.

Lupu, Noam. 2013. "Party Brands and Partisanship: Theory with Evidence from a Survey 
Experiment in Argentina.” American Journal of Political Science 57 (1): 49-64.

Lupu, Noam. 2014. "Brand Dilution and the Breakdown of Political Parties in Latin America." World Politics 66 (4): 561-602.

Lupu, Noam. 2015a. "Partisanship in Latin America." In The Latin American Voter: Pursuing Representation and Accountability in Challenging Contexts, ed. R. E. Carlin, M. M. Singer and E. J. Zechmeister. Ann Arbor: University of Michigan Press, pp. 226-45.

Lupu, Noam. 2015b. "Party Polarization and Mass Partisanship: A Comparative Perspective.” Political Behavior 37 (2): 331-56.

Lupu, Noam. 2016. Party Brands in Crisis: Partisanship, Brand Dilution, and the Breakdown of Political Parties in Latin America. Cambridge: Cambridge University Press.

Lupu, Noam, and Susan C. Stokes. 2010. "Democracy, interrupted: Regime change and partisanship in twentieth-century Argentina.” Electoral Studies 29 (1): 91-104.

Lupu, Noam, and Susan C. Stokes. 2009. "The Social Bases of Political Parties in Argentina, 1912-2003.” Latin American Research Review 44 (1): 58-87.

Mainwaring, Scott, and Timothy R. Scully. 1995. "Introduction: Party Systems in Latin America." In Building Democratic Institutions: Party Systems in Latin America, eds. Scott Mainwaring and Timothy R. Scully. Stanford, CA: Stanford University Press. 134.

Malloy, James M. 1991. "Democracy, Economic Crisis and The Problem of Governance: The Case of Bolivia." Studies in Comparative International Development 26 (2): 37-57.

Mayorga, René Antonio. 2005. "Bolivia’s Democracy at the Crossroads." In The Third Wave of Democratization in Latin America: Advances and Setbacks, eds. Frances Hagopian and Scott Mainwaring. Cambridge: Cambridge University Press. 149-78.

Mayorga, René Antonio. 1997. “Bolivia’s Silent Revolution.” Journal of Democracy 8 (1): $142-56$.

Morales Quiroga, Mauricio. 2008. “La Primera Mujer Presidenta de Chile: ¿Qué explicó el triunfo de Michelle Bachelet en las elecciones de 2005-2006?”. Latin American Research Review 43 (1): 7-32.

Morgan, Jana. 2011. Bankrupt Representation and Party System Collapse. University Park, PA: Pennsylvania State University Press.

Murillo, María Victoria. 2001. Labor Unions, Partisan Coalitions, and Market Reforms in Latin America. New York: Cambridge University Press. 
Mustapic, Ana María. 2005. “Inestabilidad sin colapso: La renuncia de los presidentes: Argentina en el ano 2001.” Desarrollo Económico 45 (178): 263-80.

Mustapic, Ana María, and Matteo Goretti. 1992. “Gobierno y oposición en el Congreso: La práctica de la cohabitación durante la presidencia de Alfonsín (1983-1989).” Desarrollo Económico 32 (126): 251-69.

Navia, Patricio, and Ricardo Godoy. 2014. “The Alianza’s Quest to Win Power Democratically." In Democratic Chile: The Politics and Policies of a Historic Coalition, 1990-2010, eds. Kirsten Sehnbruch and Peter M. Siavelis. Boulder, CO: Lynne Rienner Publishers. 43-68.

Nichter, Simeon. 2008. "Vote Buying or Turnout Buying? Machine Politics and the Secret Ballot.” American Political Science Review 102 (1): 19-32.

O’Neill, Kathleen. 2005. Decentralizing the State: Elections, Parties, and Local Power in the Andes. Cambridge: Cambridge University Press.

Payne, J. Mark, Daniel Zovatto G., and Mercedes Mateo Díaz. 2007. Democracies in Development: Politics and Reform in Latin America. Washington, D.C.: Inter-American Development Bank.

Penfold, Michael. 2009. Dos tradiciones, un conflicto: El futuro de la descentralización. Caracas: Debate.

Pope, Jeremy C., and Jonathan Woon. 2009. "Measuring Changes in American Party Reputations, 1939-2004.” Political Research Quarterly 62 (4): 653-61.

Portes, Alejandro. 1970. "Leftist Radicalism in Chile: A Test of Three Hypotheses." Comparative Politics 2 (2): 251-74.

Posner, Paul W. 1999. "Popular Representation and Political Dissatisfaction in Chile's New Democracy.” Journal of Interamerican Studies and World Affairs 41 (1): 59-85.

Remmer, Karen L. 2008. "The Politics of Institutional Change: Electoral Reform in Latin America, 1978-2002.” Party Politics 14 (1): 5-30.

Roberts, Kenneth M. 2003. "Social Correlates of Party System Demise and Populist Resurgence in Venezuela.” Latin American Politics and Society 45 (3): 35-57.

Roberts, Kenneth M. 2014. Changing Course: Parties, Populism, and Political Representation in Latin America's Neoliberal Era. Cambridge: Cambridge University Press.

Sartori, Giovanni. 1976. Parties and Party Systems: A Framework for Analysis. Cambridge: Cambridge University Press. 
Seawright, Jason. 2012. Party-System Collapse: The Roots of Crisis in Peru and Venezuela. Stanford, CA: Stanford University Press.

Siavelis, Peter M. 2000. The President and Congress in Post-Authoritarian Chile: Institutional Constraints to Democratic Consolidation. University Park, PA: Pennsylvania State University Press.

Siavelis, Peter M. 2009. "Enclaves de la transición y democracia chilena.” Revista de Ciencia Política 29 (1): 3-21.

Siavelis, Peter M. 2014. "From a Necessary to a Permanent Coalition.” In Democratic Chile: The Politics and Policies of a Historic Coalition, 1990-2010, eds. Kirsten Sehnbruch and Peter M. Siavelis. Boulder, CO: Lynne Rienner Publishers. 15-42.

Silva, Patricio. 2001. "Towards Technocratic Mass Politics in Chile? The 1999-2000 Elections and the 'Lavín Phenomenon'.” European Review of Latin American and Caribbean Studies 70 25-39.

Singer, Matthew M. 2004. "The 2002 presidential and parliamentary elections in Bolivia." Electoral Studies 23 (1): 172-82.

Slater, Dan, and Erica Simmons. 2013. “Coping by Colluding: Political Uncertainty and Promiscuous Powersharing in Indonesia and Bolivia.” Comparative Political Studies 46 (11): 1366-93.

Snow, Peter G. 1971. Political Forces in Argentina. New York: Praeger.

Stokes, Donald E. 1992. "Valence Politics.” In Electoral Politics, ed. D. Kavanagh. New York: Oxford University Press, pp. 141-64.

Stokes, Susan C. 2001. Mandates and Democracy: Neoliberalism by Surprise in Latin America. Cambridge: Cambridge University Press.

Stokes, Susan C., Thad Dunning, Marcelo Nazareno, and Valeria Brusco. 2013. Brokers, Voters, and Clientelism. Cambridge: Cambridge University Press.

Sundquist, James L. 1983. Dynamics of the Party System: Alignment and Realignment of Political Parties in the United States. Washington, D.C.: Brookings Institution Press.

Tavits, Margit. 2007. "Principle vs. Pragmatism: Policy Shifts and Political Competition.” American Journal of Political Science 51 (1): 151-65.

Tironi, Eugenio, and Felipe Agüero. 1999. “¿Sobrevivirá el nuevo paisaje político chileno?”. Estudios Públicos 74 151-68.

Tomz, Michael, and Robert P. Van Houweling. 2009. “The Electoral Implications of Candidate 
Ambiguity.” American Political Science Review 103 (1): 83-98.

Torcal, Mariano, and Scott Mainwaring. 2003. "The Political Recrafting of Social Bases of Party Competition: Chile, 1973-95.” British Journal of Political Science 33 (1): 55-84.

Tuesta Soldevilla, Fernando, ed. 1996. Los Enigmas del Poder: Fujimori 1990-1996. Lima: Fundación Friedrich Ebert.

Tulchin, Joseph S., and Andrew Selee, eds. 2004. Decentralization and Democratic Governance in Latin America. Washington, D.C.: Woodrow Wilson International Center for Scholars.

Turner, John C. 1999. "Some Current Issues in Research on Social Identity and SelfCategorization Theories.” In Social Identity: Context, Commitment, Content, eds. Naomi Ellemers, Russell Spears and Bertjan Doosje. Malden, MA: Blackwell. 6-34.

Turner, John C., Michael A. Hogg, Penelope Oakes, Stephen Reicher, and Margaret Wetherell. 1987. Rediscovering the Social Group: A Self-Categorization Theory. New York: Blackwell.

Valenzuela, Arturo. 1978. The Breakdown of Democratic Regimes: Chile. Edited by Juan J. Linz and Alfred Stepan, The Breakdown of Democratic Regimes. Baltimore: The Johns Hopkins University Press.

Valenzuela, Samuel J. 1999. "Reflexiones sobre el presente y futuro del paisaje político chileno a la luz de su pasado.” Estudios Públicos 75 273-90.

Valenzuela, Samuel J., and Timothy R. Scully. 1997. "Electoral Choices and the Party System in Chile: Continuities and Changes at the Recovery of Democracy." Comparative Politics 29 (4): 511-27.

Van Cott, Donna Lee. 2003. “From Exclusion to Inclusion: Bolivia’s 2002 Elections.” Journal of Latin American Studies 35 (4): 751-75.

Van Cott, Donna Lee. 2005. From Movements to Parties in Latin America: The Evolution of Ethnic Politics. Cambridge: Cambridge University Press.

Weitz-Shapiro, Rebecca. 2013. "What Wins Votes: Why Some Politicians Opt Out of Clientelism.” American Journal of Political Science 56 (3): 563-83.

Whitehead, Laurence. 1986. "Bolivia's Failed Democratization, 1977-1980.” In Transitions from Authoritarian Rule: Latin America, eds. Guillermo O’Donnell, Philippe C. Schmitter and Laurence Whitehead. Baltimore: The Johns Hopkins University Press. 49-71.

Whitehead, Laurence. 2001. "High Anxiety in the Andes: Bolivia and the Viability of 
Democracy.” Journal of Democracy 12 (2): 6-16.

Wiesehomeier, Nina, and David Doyle. 2012. “Attitudes, Ideological Associations and the LeftRight Divide in Latin America.” Journal of Politics in Latin America 4 (1): 3-33. 
Figure 1. Electoral strength of the UCR, MNR, and Concertación

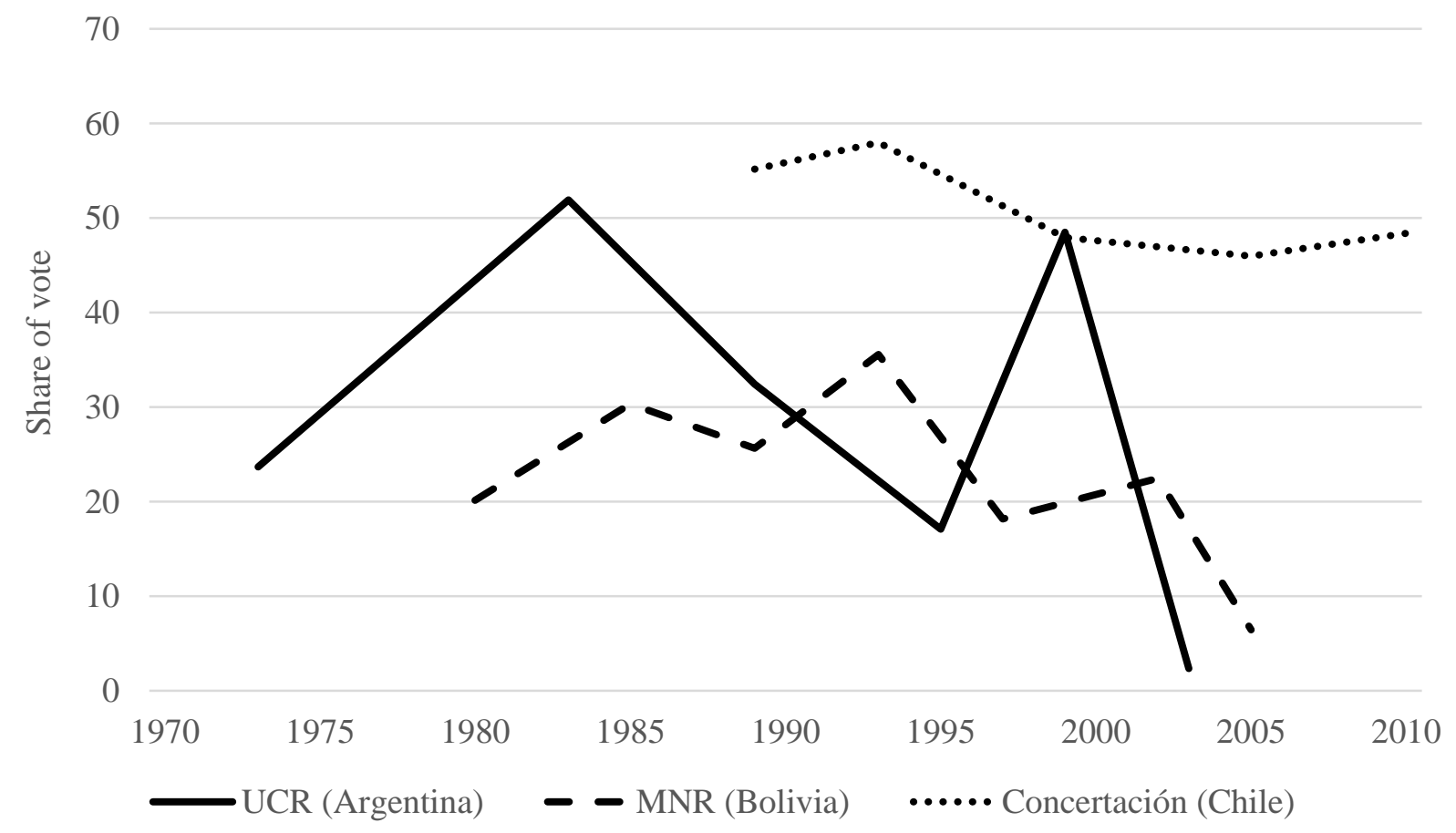

Notes: Lines represent share of the vote for each party in the first round of presidential elections.

Sources: Payne et al. (2007) and author's updates 
Figure 2. Party convergence in Bolivia and Chile
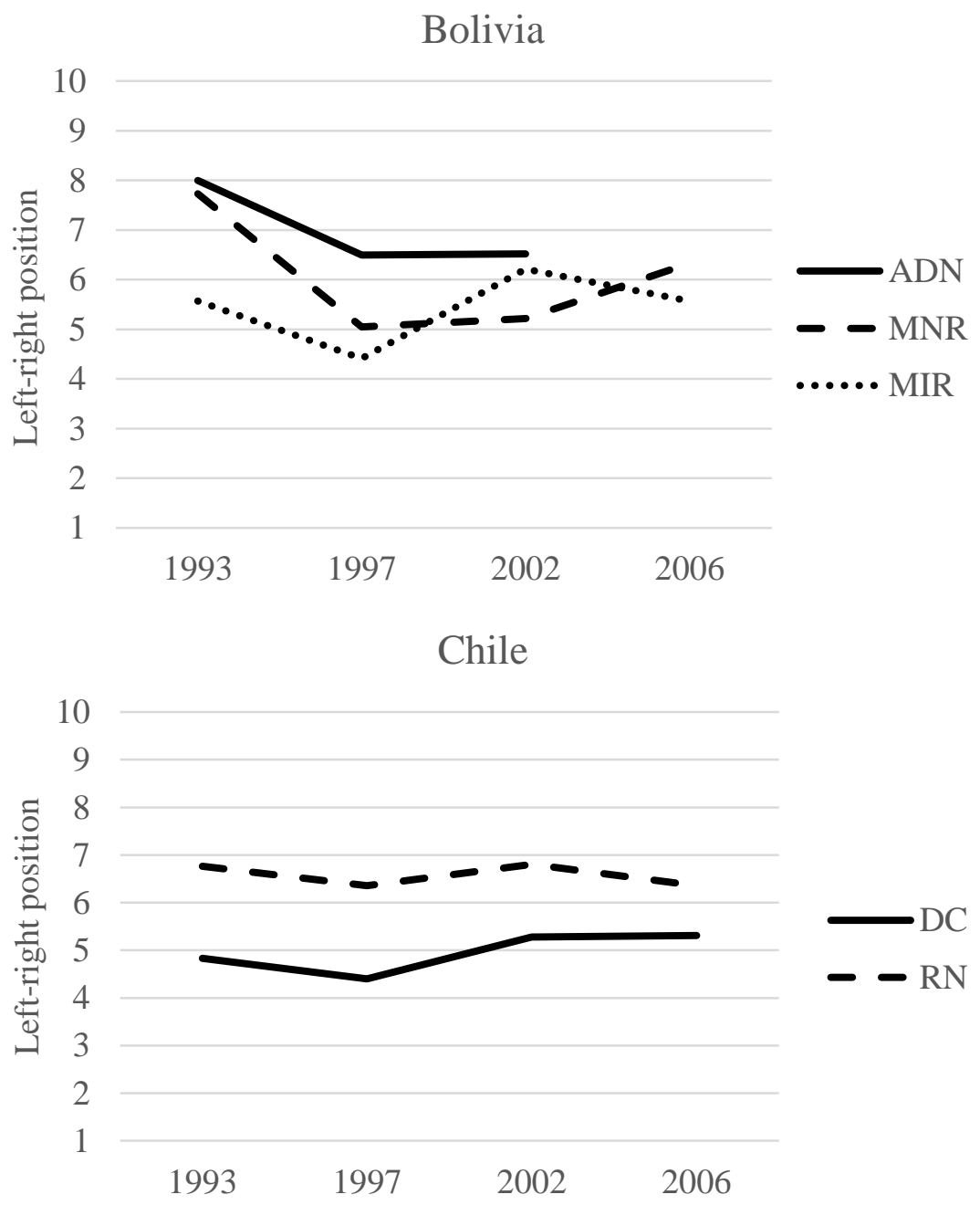

Notes: Lines represent changes over time in parties' left-right positions.

Sources: USAL surveys 
Figure 3. Partisanship and party polarization in Chile, 1990-2009

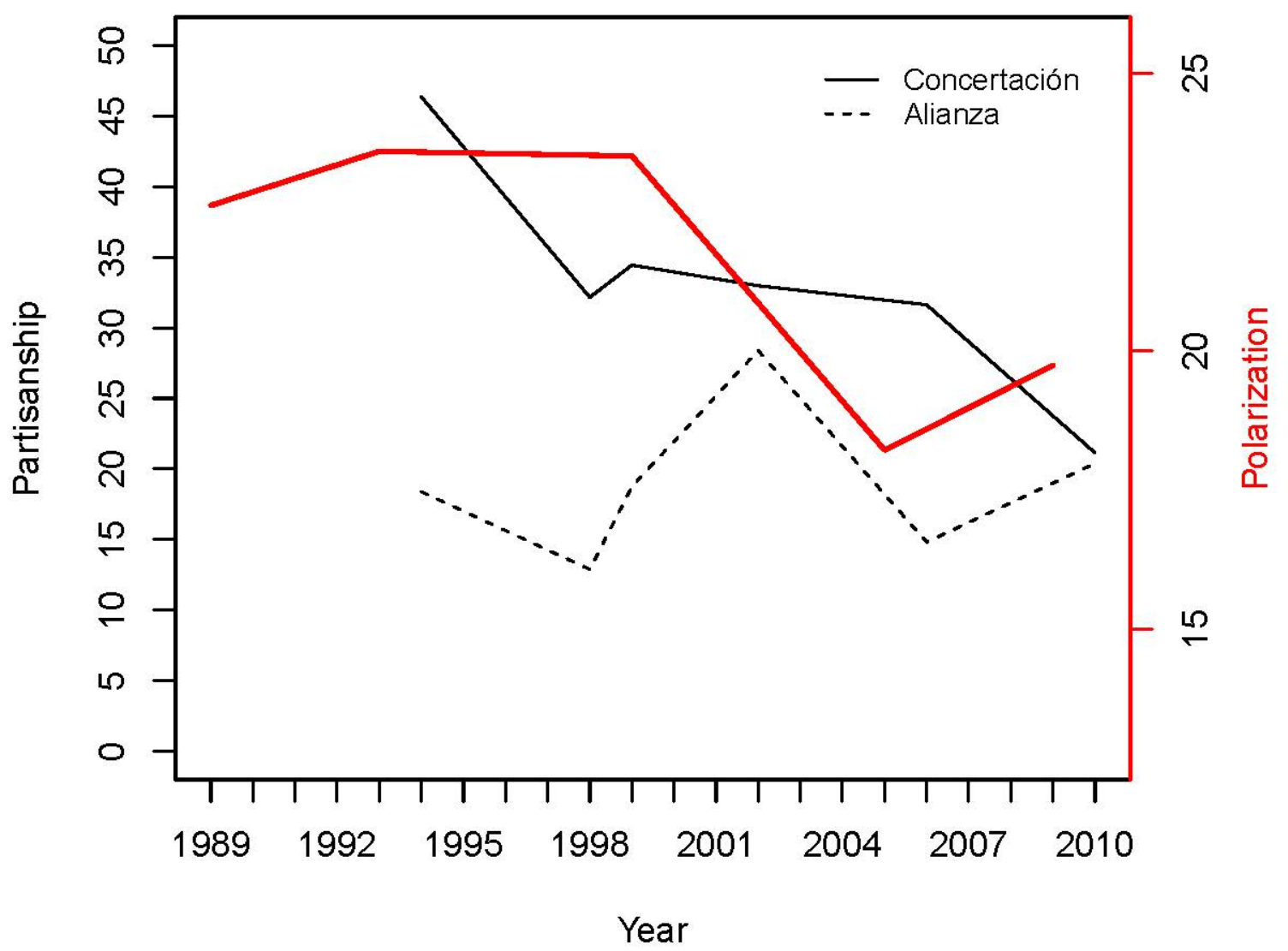

Notes: Black lines represent proportions of respondents from national surveys who said they identified with each coalition. The red line represents the ideological distance based on party manifestos between the Concertación and Alianza.

Sources: Centro de Estudios Públicos and Gamboa et al. (2013) 